Modelling flow and sediment trapping upstream and within grass buffer strips Sina Akram ${ }^{1 . *}$, Bofu $\mathrm{Yu}^{2}$, Hossein Ghadiri ${ }^{1}$

${ }^{1}$ Environmental Futures Research Institute, School of Environment, Griffith University, Australia

${ }^{2}$ School of Engineering, Griffith University, Australia

* Correspondence to: Sina Akram, Mailbox 15, School of Environment (N55), Griffith University, 170 Kessels Road, Nathan, QLD 4111, Australia.

E-mail address: s.akram@griffith.edu.au 


\title{
Modelling flow and sediment trapping upstream and within grass buffer strips
}

Running head: Modelling flow and sediment trapping upstream and within grass strips

\begin{abstract}
Grass buffer strips impact the hydrology of flow and consequently the fate of sediment. A complex process-based model is developed to predict flow characteristics as well as sediment deposition and transport upstream, and within grass strips. The model is capable of estimating proportion and amount of different sediment particle size classes in the outflow. The modified Green-Ampt equation was used to simulate infiltration. Gradually varied flow and kinematic wave approximation were used to model flow characteristics upstream and within grass strips. The GUEST model approach has been modified in order to use its basic approaches in sediment transport module in grass strips. Model predictions agree well with the results of two sets of controlled experiments. The bias, coefficient of model efficiency, and the root mean squared error of the modelled efficiency of grass strips in reducing sediment concentration were 0.930.99, 0.58-0.99, and 8.9-12.7 respectively. The sensitivity analysis showed that the initial soil moisture and flow rate are the most sensitive parameters in predicting runoff loss. Increasing the slope steepness and flow rate dramatically decreases the efficiency of grass strips in reducing sediment concentration and mass.
\end{abstract}

Keywords: Model, Sediment, Grass strip, Flow, Buffer strip

\section{Introduction}

Grass strips have been extensively tested and used to alleviate sediment and associated pollutants delivery to rivers (Abu-Zreig et al., 2004; Dabney et al., 1993; Hook, 2003; Parsons et al., 1994; Raffaelle et al., 1997; Rey, 2004). The two processes of increased roughness and infiltration enhance trapping of sediment particles upstream and within grass strips (Akram et al., 2014; Deletic and Fletcher, 2006; Le Bissonnais et al., 2004; Schmitt et al., 1999; Shrestha et al., 2005).

A number of models have been developed to predict the performance of grass strips in removing sediment. Although these models have helped decision makers in adopting the technology, the models are not yet capable of accurately and explicitly describe the sediment transport and deposition processes in time and space.

Munoz-Carpena et al. (1999) developed the VFSMOD model for predicting hydrology and sediment transport in vegetative filter strips. The hydrology module is fully process-based and 
is based on kinematic wave flow and Green-Ampt infiltration equations. In VFSMOD the University of Kentucky sediment transport module is linked to the new hydrology module to predict the sediment filtration in grass strips (Munoz-Carpena et al., 1999). Although the VFSMOD model considers both upstream and within grass strip as deposition areas, the model could not accurately predict the amount and size distribution of sediment in the outflow. The University of Kentucky sediment transport module is based on laboratory experiments, and is one of the most cited water and sediment transport models through vegetated strips. Adding a fully process-based hydrology module to the Kentucky's model has made predictions of VFSMOD more accurate than the Kentucky’s model. VFSMOD, however, does not consider the detachment process in sediment transport through vegetated filter strips. Laboratory measurement shows that the Kentucky's model is not sufficiently accurate in dealing with small particles and low concentrations (Deletic, 1999; Deletic, 2000). VFSMOD also has limitations in dealing with sediment of highly distributed sizes and concentrations (Hussein et al., 2007b).

TRAVA is another model developed to predict the effects of grass strips on flow hydrology and sediment transport (Deletic, 2001; Deletic, 2005). The hydrology sub-model of TRAVA is similar to the one used in VFSMOD. TRAVA uses a series of empirical equations based on experiments carried out for developing the sediment sub-model (Deletic, 1999; Deletic, 2000). TRAVA is able to model the particle size distribution in the outflow. This has made the model potentially applicable for pollution assessment if a sorbed nutrients transport submodel is added to it. Similar to other empirical models TRAVA's performance is limited to the experimental conditions and has not been tested with a wide range of input data. It also does not consider the backwater region upstream of grass strips as an area of deposition. According to Hussein et al. (2007b) experiments, a major fraction of deposition occurs upstream from grass buffer strips.

Newham et al. (2005) developed the RPM model for predicting the trapping efficiency of riparian buffers through settling, infiltration and adhesion (adsorption) processes. The model divides the sediment load into two size classes of: a) coarse $(>50 \mu \mathrm{m})$ particles that are trapped by settling, and $\mathrm{b})$ fine $(\leq 50 \mu \mathrm{m})$ particles that are trapped through infiltration and adhesion processes. Inclusion of sediment infiltration and adhesion as separate parts of sediment transport processes is unique to the RPM model. RPM, however, does not explicitly model the settling process in either backwater or inside vegetated strip, and also does not consider the detachment process. As the model does not divide inflow sediment into different size classes, its results cannot be implemented to predict water pollution. 
WEPP (Nearing et al., 1989) is a process-based, steady-state continuous model of erosion and sediment transport. Flanagan and Nearing (2000) evaluated WEPP performance in predicting sediment fate in grass strips by comparing the model outcomes with experimental results. WEPP does not track sediment in the backwater region and tends to under-predict the proportion of fine size particles and over-predict the fraction of medium-sized particles in the outflow. This can bring about uncertainties if the model is used to predict pollutants associated with sediments delivered to streams.

A number of statistical models have also been developed to predict the efficiency of grass strips in trapping sediments (Andriyas et al., 2003). Although the prediction accuracy of such statistical models is higher than process-based models in general, they cannot explicitly simulate the processes occurring during a runoff event.

The objectives of the paper are 1) to develop a new approach for predicting the fate of water and sediment in and around grass buffer strips, and 2) to test the performance of this new model with two sets of controlled experimental data, and 3) to assess model sensitivity in order to clarify the effect and importance of various factors in the performance of grass strips. The highlight of this new model is the process-based simulation of the combined effect of buffer strips on sedimentation upstream and vegetation induced infiltration and sedimentation within the buffer strip. This has not been achieved in the papers reviewed above. The research by Hussein et al. (2007b) which simulates the hydrology and sediment transport in the upstream section from grass strips is extended in this paper to include what occurs inside buffer strips. The model is based on Hairsine and Rose (1992) method, which assumes that soil erosion and deposition processes occur simultaneously.

\section{Model structure}

The model, hence called Griffith University Soil Erosion \& Deposition-Vegetative Buffer Strips 2 (GUSED-VBS 2), is a process-based model which simulates the deposition and erosion processes upstream and within grass buffer strips in single runoff events.

Following assumptions have been made in developing this model:

- The inflow is steady and subcritical.

- Deposition and re-entrainment (detachment of deposited sediment by overland flow) are the two main processes occur concurrently which change sediment concentration along the path. 
- As the length of backwater is short and the permeability of bare soil is dramatically lower than vegetated ground, infiltration is neglected in the upstream region.

- Particles are trapped due to infiltration regardless of their size.

- Deposited mass due to infiltration settles on the soil top and does not percolate within.

- Vegetation is non-submerged.

Fig 1 shows the hypothetical scheme of the water and deposited profile upstream and within a grass strip. Water depth increases in the backwater region upstream the grass strip as flow approaches the buffer. Thus the flow velocity decreases, enhancing coarse particles settlement in this region. Moreover the frictional slope is very low in this section compared to its upstream and downstream sections. Low frictional slope results in low stream power and consequently high net deposition (Akram et al., 2014). As the actual velocity and frictional slope are higher in grass strip compared to the backwater region, settling due to higher resistance is lower. Infiltration decreases the flow rate and consequently the mass of sediment in the outflow. As infiltration decreases the flow rate, the flow velocity dwindles, therefore due to lower stream power the probability of deposition increases. If significant length of backwater appears upstream, high proportion of coarse particles settle in this region, therefore the particles enter the grass strip is consisted mostly of fine particles that could not settle in the backwater region.

Hydrology and sediment transport are modelled primarily in the upstream region. Water depth and sediment concentration of different particle size classes at the upstream end of backwater region in every time step are considered as initial conditions within buffers. Gradually varied flow equation is used to calculate flow characteristics upstream the grass strip: 
$\frac{d D}{d x}=\frac{S_{0}-S_{f}}{1-F r^{2}}$

where $D$ is the water depth (m), $x$ is the downslope distance $(\mathrm{m}), S_{0}$ is the bed slope $\left(\mathrm{m} \mathrm{m}^{-1}\right), S_{f}$ is the frictional slope $\left(\mathrm{m} \mathrm{m}^{-1}\right)$, and $F r$ is the Froude number.

Change of sediment concentration over distance is calculated using the following equations:

$q \frac{d c_{\mathrm{i}}}{d x}=-v_{\mathrm{i}} c_{\mathrm{i}}+H r_{\max } \frac{v_{\mathrm{i}} c_{\mathrm{i}}}{\sum v_{\mathrm{i}} c_{\mathrm{i}}}$

$r_{\max }=\frac{F \sigma\left(\Omega-\Omega_{\mathrm{o}}\right)}{g(\sigma-\rho) D}$

$\Omega=\rho g q S_{f}$

where $q$ is the unit flow rate $\left(\mathrm{m}^{3} \mathrm{~m}^{-1} \mathrm{~s}^{-1}\right), c_{i}$ is the sediment concentration in size class $i\left(\mathrm{~kg} \mathrm{~m}^{-}\right.$ $\left.{ }^{3}\right), v_{i}$ is the fall velocity for size class $i\left(\mathrm{~m} \mathrm{~s}^{-1}\right), H$ is the ratio of soil covered by deposited sediment to the whole area, $r_{\max }$ is the maximum rate of entrainment $\left(\mathrm{kg} \mathrm{m}^{-2} \mathrm{~s}^{-1}\right), F$ is the available stream power available for entraining particles, $\sigma$ is the wet density of sediments (kg $\left.\mathrm{m}^{-3}\right), \Omega$ and $\Omega_{o}$ are stream power and threshold stream power per unit area $\left(\mathrm{W} \mathrm{m}^{-2}\right)$, and $\rho$ is the water density $\left(\mathrm{kg} \mathrm{m}^{-3}\right)$.

The distribution of particle size classes is to be given as input data to the model. Settling velocity for every class is estimated using Cheng method (Cheng, 1997):

$$
\begin{aligned}
& v_{\mathrm{i}}=\frac{\left(\sqrt{25+1.2 d_{*}^{2}}-5\right)^{1.5} \vartheta}{d} \\
& d_{*}=\left(\frac{(\sigma-\rho)}{\rho \vartheta^{2}} g\right)^{1 / 3} d
\end{aligned}
$$

where $v$ is the kinematic viscosity $\left(\mathrm{m}^{2} \mathrm{~s}^{-1}\right)$, and $d$ is the mean diameter of the particle size class (m). Cheng method is applicable to both laminar and turbulent flow regimes.

Deposition and entrainment processes change the bed elevation. The model is able to dynamically change the slope by:

$\frac{d z}{d t}=-\frac{q}{\sigma(1-\lambda)} \frac{d c}{d x}$ 
$S_{0}=\frac{d z}{d x}$

where $z$ is the bed level (m), $\lambda$ is porosity, and $t$ is time (s).

Equations 1 to 8 are identical to those used in (Hussein et al., 2007b).

The processes within grass strips are more complex. Infiltration intensifies particles settling; the infiltration rate is therefore also added to the settling velocity of each particle size class. The other complexity of the processes within the grass strip is that the flow is gradually varied, and unsteady.

Kinematic wave approximation is used in order to predict flow characteristics spatially and temporally along grass strip by the following equations:

The continuity equation:

$\frac{\partial q}{\partial x}+\frac{\partial D}{\partial t}=-f$

Manning formula is used as the momentum equation:

$q=\frac{1}{n} D^{5 / 3} S_{f}^{0.5}$

where $f$ is the infiltration rate $\left(\mathrm{m} \mathrm{s}^{-1}\right)$, and $n$ is the equivalent Manning roughness coefficient inside grass strips.

The surface flow module is coupled with the Infiltration module which is based on modified Green-Ampt method:

The continuity equation:

$\frac{\partial y}{\partial t}=\frac{f}{\theta_{s}-\theta_{i}}$

Darcy's formula is used as the momentum equation:

$f=K_{s} \frac{\left|h_{c}\right|+y+D}{y}$ 
where $y$ is the depth of wet front (m), $\theta_{s}$ is the water content of the soil while saturated, $\theta_{i}$ is the initial water content of the soil, $K_{s}$ is the saturated hydraulic conductivity ( $\mathrm{m} \mathrm{s}^{-1}$ ), and $h_{c}$ is the capillary fringe pressure $(\mathrm{m})$.

As the actual cross section area within a grass strip is lower than calculated one (due to the area covered by leaves and foliage), following equation is used to estimate the actual flow rate:

$q_{a}=\frac{q}{(1-B l)}$

where $q_{a}$ is the actual flow rate $\left(\mathrm{m}^{2} \mathrm{~s}^{-1}\right)$, and $B l$ is the fraction of cross section which is covered by stems and foliage.

Sediment transport processes are described by the following equation:

$q_{a} \frac{d c_{\mathrm{i}}}{d x}=-\left(v_{\mathrm{i}}+f\right) c_{\mathrm{i}}+H r_{\max } \frac{v_{\mathrm{i}} c_{\mathrm{i}}}{\sum v_{\mathrm{i}} c_{\mathrm{i}}}$

Changes in topography over time within grass strips are calculated using the following equation:

$\frac{d z}{d t}=-\frac{1}{\sigma(1-\lambda)} \frac{d\left(q_{a} c\right)}{d x}$

\section{Computational scheme and numerical solutions}

\section{Upstream of the grass strip}

The flow rate and sediment concentration upstream of the backwater region are assumed to be steady and to be given to the model as input data. The water depth at the upstream edge of the backwater region is equal to the normal depth of the flow over the bare soil. The downstream depth of water in the backwater region is the normal depth of the steady flow over the grass strip.

The equations for predicting the flow and sediment characteristics upstream of the grass strip (eqs 1 and 2) were solved using the fourth order Runge-Kutta method. As the downstream water depth which is equal to the normal depth of the flow within the grass strip is the control point for solving equation 1 and the concentration of particles of different size classes upstream of the backwater were control points for equation 2 , the two equations solved separately and results from equation 1 were used for solving the equation 2 . The equations were solved at 
every time step taking the topography at the end of the previous time step as the initial condition for the next.

\section{Within the grass strip}

The sediment concentrations of different particle size classes at the entrance of the grass strip, which are the outputs of the "upstream" module, are taken as the upstream boundary condition for the "within the grass strip" module. The flow rate considering the infiltration rate at every time step at the lower edge of grass strip is a boundary condition for the numerical calculations. The water depth at the lower edge is equal to the normal depth of the corresponding flow rate over the bare soil.

The ordinary differential equation of the infiltration module (Eq 11) was solved using the fourth order Runge-Kutta method. The kinematic wave module was numerically solved utilising finite difference techniques. Fully implicit method was used to solve the kinematic wave partially differential equations (Eqs 9 and 10). Equation 14 was solved using fourth order Runge-Kutta method.

\section{Model application and validation}

The performance of the model in predicting the fate of water and sediment in and around grass strips was evaluated by comparing the model outcomes with the results of two separate sets of experiments. The first set of experiments was carried out by Jin and Romkens (2001) in an experimental flume using artificial grass. The second set was based in Griffith University and conducted by Hussein et al. (2006).

\section{The first set of experiments (Jin and Romkens, 2001)}

The tests were carried out in a laboratory flume evaluating the effects of different grass densities, bed slopes, flow rates, particle size distribution, and concentrations on fate of sediment upstream and within the vegetated area. Vegetation was simulated with polypropylene bristles which were inserted and glued in a staggered pattern. The surface was impermeable and infiltration effects were not tested. The length of the grassed part and the upstream zone were 2.4 and $1.2 \mathrm{~m}$ respectively. Two different grass densities of 2500 and 10000 bunches of four bristles per square meter were used to see the effects of grass density on sediment retention. Three different particle size distributions of coarse sand, fine sand, and silt loam were used in a steady run-on to evaluate the influence of grass strips on the fate of 
different particle sizes and combinations. Sediment was uniformly mixed in a tank and steady flow was distributed in the flume. Durations of the events were between 80 and 140 minutes.

Deposited sediments in the upstream area, and in the upper half and lower half of the grass strip were collected after every event. The collected samples were oven dried and sieved through a nest of sieves to measure the fraction of different size classes in the deposited sediment. Run-on samples were also collected every two to three minutes at the outlet to measure the concentration of different size classes in the outflow. More details can be found in Jin and Romkens (2001). The parameters used to simulate the experimental conditions in the model are given in Table 1.

Table1. Model parameters and their values for Jin and Romkens (2001) experiment

\begin{tabular}{|c|c|c|c|c|c|}
\hline Module & Parameter & Symbol & Unit & $\begin{array}{l}\text { Values (Jin and } \\
\text { Ramkens, 2001) }\end{array}$ & $\begin{array}{l}\text { Values (Hussein et } \\
\text { al., 2006) }\end{array}$ \\
\hline \multirow[t]{11}{*}{ Hydrology } & Buffer width & $\mathrm{b}$ & $\mathrm{m}$ & 0.64 & 0.3 \\
\hline & Buffer length & $\mathrm{L}_{\text {in }}$ & $\mathrm{m}$ & 2.4 & 0.3 \\
\hline & Upstream length & $\mathrm{L}_{\text {up }}$ & $\mathrm{m}$ & 1.2 & 1.8 \\
\hline & Upstream Manning coefficient & $\mathrm{n}_{\mathrm{up}}$ & $\mathrm{s} \mathrm{m}^{-1 / 3}$ & 0.015 & 0.04 \\
\hline & Grass Manning coefficient & $\mathrm{n}$ & $\mathrm{s} \mathrm{m}^{-1 / 3}$ & 0.075 in low density & 0.8 \\
\hline & & & & 0.12 in high density & \\
\hline & Width blocked by grass & $\mathrm{BI}$ & - & 0.01 for low density & 0.3 \\
\hline & & & & 0.04 for high density & \\
\hline & Flow rate & $\mathrm{Q}$ & $\mathrm{L} \mathrm{s}^{-1}$ & $1.45-7$ & $0.3-1.0$ \\
\hline & Surface slope & $\mathrm{S}_{0}$ & $\%$ & $2-6$ & $1-5$ \\
\hline & Infiltration rate & $f$ & $\mathrm{~m} \mathrm{~s}^{-1}$ & 0 & 0 \\
\hline \multirow[t]{10}{*}{ Sediment } & Kinematic viscosity of water & v & $m^{2} s^{-1}$ & $10^{-6}$ & $10^{-6}$ \\
\hline & Sediment concentration & c & $\mathrm{kg} \mathrm{m}^{-3}$ & $1.44-7$ & $4.7-25.2$ \\
\hline & Effective excess stream power & $\mathrm{F}$ & - & 0.1 in upstream area & 0.1 in upstream area \\
\hline & & & & 0.002 in grassed zone & 0.002 in grassed zone \\
\hline & Water density & $\rho$ & $\mathrm{kg} \mathrm{m}^{-3}$ & 1000 & 1000 \\
\hline & Sediment density & & & 2630 for coarse sand & 1600 for Ferralsol \\
\hline & & & & 2630 for coarse sand & 2500 for Podzol \\
\hline & & & & 2520 for silt loam & 1600 for Vertisol \\
\hline & Deposited sediment porosity & $\lambda$ & - & 0.4 & 0.4 \\
\hline & Threshold stream power & $\Omega_{0}$ & $\mathrm{~kg} \mathrm{~m}^{-3}$ & 0.008 & 0.008 \\
\hline
\end{tabular}

The second set of experiments (Hussein et al., 2006) 
Data from flume experiments carried out with Griffith University Tilting-flume Simulated Rainfall facility (GUTSR) was used to test GUSED-VBS 2 performance. Three different soil textures were used to introduce different particle size distributions in the inflow. Sediment was uniformly mixed in a tank and steady flow was maintained in the flume. The strip was consisted of naturally grown vetiver grass (Vetiveria zizaniodes L.) with the length of $0.3 \mathrm{~m}$. The density of grass was $4300 \mathrm{stems} / \mathrm{m}^{2}$. Flow rates were steady and varied between 0.00033 to $0.001 \mathrm{~m}^{3}$ $\mathrm{s}^{-1} \mathrm{~m}^{-1}$. The flume bed was impermeable, therefore no infiltration occurred. Each test took 20 minutes.

The collected samples were oven dried and sieved through a series of sieves to measure the fraction of different size classes in the outflow. More details can be found in Hussein et al. (2006) and Hussein et al. (2007a). The parameters used to simulate the experimental conditions in the model are as Table 1.

The model results were compared with the observed data using different evaluation techniques. The "Bias" of the model was calculated from the model predictions and observations as:

$$
\operatorname{Bias}=\frac{\sum M_{i}}{\sum O_{i}}
$$

where $M_{i}$ and $O_{i}$ are modelled and observed data respectively. The Bias criterion shows whether the model over-estimates or under-estimates the observations on average.

The observed data of grass strips of different conditions were also compared to the model predictions. The coefficient of model efficiency Ec (Nash and Sutcliffe, 1970) was calculated from the observations and model output as:

$E c=1-\frac{\sum\left(O_{i}-M_{i}\right)^{2}}{\sum\left(O_{i}-\bar{O}\right)^{2}}$

where $\bar{O}$ is the average of the observed values. The model efficiency $(E c)$ measures the level of accordance between the modelled and observed values. Ec value of 1 indicates perfect agreement.

In addition, the root mean squared error (RMSE) was calculated as:

$$
R M S E=\sqrt{\frac{1}{N} \sum\left(O_{i}-M_{i}\right)^{2}}
$$


where $N$ is the number of observations. RMSE quantifies the error in the modelled values in the unit of the original variable. RMSE equal to zero shows the perfect fit and the lower the RMSE value, the better the agreement. RMSE\% (RMSE/D) was also calculated to represent the relative magnitude of errors.

The Pearson product-moment correlation coefficient ( $P W M$ ) was the other criterion used for assessing the accuracy of model predictions as:

$P W M=\frac{\sum M_{i}}{\sum O_{i}} \frac{n \sum O_{i} M_{i}-\left(\sum O_{i}\right)\left(\sum M_{i}\right)}{\sqrt{n \sum O_{i}^{2}-\left(\sum O_{i}\right)^{2}} \sqrt{n \sum M_{i}^{2}-\left(\sum M_{i}\right)^{2}}}$

$P W M$ is a criterion, expressing the linear correlation between observed measurements and modelled outcomes. PWM equal to 1 indicates the perfect match between observed and modelled efficiencies.

\section{Results}

Jin and Romkens (2001) experiment:

The model was run for every scenario tested in the first set of experiments (Jin and Romkens, 2001) and the results are shown in Table 2. In this table the modelled and observed rates of deposition in the upstream section, upper half, and lower half of the grass strip are compared. Table 3 shows the performance indicators for this set of flume experiments. 


\begin{tabular}{|c|c|c|c|c|c|c|c|c|c|c|c|c|c|c|}
\hline \multirow[t]{3}{*}{ Test } & \multirow{3}{*}{$\begin{array}{l}\text { Grass } \\
\text { density }\end{array}$} & \multirow[t]{3}{*}{ Sediment type } & \multirow{3}{*}{$\begin{array}{l}\text { Q } \\
\left(\mathrm{m}^{3} \mathrm{~s}^{-1} \times 10^{-3}\right)\end{array}$} & \multirow{3}{*}{$\begin{array}{l}\text { Duration } \\
\text { (min) }\end{array}$} & \multirow{3}{*}{$\begin{array}{l}\mathrm{c}(\mathrm{kg} \\
\left.\mathrm{m}^{-3}\right)\end{array}$} & \multirow{3}{*}{$\begin{array}{l}\mathrm{S}_{0} \\
(\%)\end{array}$} & \multicolumn{4}{|c|}{ Modelled } & \multicolumn{4}{|c|}{ Observed } \\
\hline & & & & & & & \multirow[t]{2}{*}{$\begin{array}{l}\text { Efficiency } \\
(\%)\end{array}$} & \multicolumn{3}{|c|}{$\begin{array}{l}\text { Relative deposition in different } \\
\text { positions (\%) }\end{array}$} & \multirow[t]{2}{*}{$\begin{array}{l}\text { Efficiency } \\
\text { (\%) }\end{array}$} & \multicolumn{3}{|c|}{$\begin{array}{l}\text { Relative deposition in different } \\
\text { positions (\%) }\end{array}$} \\
\hline & & & & & & & & Above & Upper & Low & & Above & Upper & Low \\
\hline 1 & Low & Fine sand & 1.7 & 102 & 1.71 & 2 & 33 & 22 & 70 & 8 & 39 & - & - & - \\
\hline 2 & Low & Fine sand & 1.84 & 85 & 3.40 & 2 & 57 & 35 & 60 & 5 & 48 & 36 & 56 & 8 \\
\hline 3 & Low & Fine sand & 1.77 & 84 & 3.08 & 2 & 55 & 43 & 52 & 5 & 58 & 41 & 51 & 8 \\
\hline 4 & Low & Fine sand & 1.73 & 88 & 4.26 & 2 & 64 & 45 & 50 & 5 & 57 & 45 & 47 & 8 \\
\hline 5 & Low & Silt loam & 2.1 & 131 & 1.44 & 2 & 56 & 68 & 31 & 1 & 57 & 11 & 77 & 12 \\
\hline 6 & Low & Fine sand & 1.96 & 90 & 4.26 & 2 & 62 & 46 & 49 & 5 & 59 & 43 & 49 & 8 \\
\hline 7 & Low & Coarse sand & 2.23 & 79 & 6.40 & 2 & 97 & 92 & 7 & 1 & 84 & 58 & 37 & 5 \\
\hline 8 & Low & Fine sand & 3.05 & 105 & 2.50 & 2 & 33 & 4 & 81 & 15 & 47 & 25 & 60 & 15 \\
\hline 9 & Low & Fine sand & 4.2 & 98 & 2.30 & 2 & 25 & 1 & 79 & 20 & 37 & 19 & 71 & 10 \\
\hline 10 & Low & Fine sand & 5.33 & 90 & 2.71 & 2 & 27 & 8 & 71 & 21 & 46 & 19 & 66 & 15 \\
\hline 11 & Low & Fine sand & 6.24 & 94 & 2.64 & 2 & 22 & 3 & 73 & 24 & 32 & 19 & 66 & 15 \\
\hline 12 & Low & Fine sand & 2.38 & 90 & 2.90 & 2 & 47 & 29 & 62 & 9 & 48 & 30 & 60 & 10 \\
\hline 13 & Low & Fine sand & 2.72 & 89 & 3.26 & 4 & 9 & 0 & 83 & 17 & 5 & 0 & 77 & 23 \\
\hline 14 & Low & Fine sand & 3.30 & 80 & 7.00 & 4 & 36 & 0 & 85 & 15 & 6 & 0 & 78 & 22 \\
\hline 15 & High & Fine sand & 5.16 & 139 & 1.61 & 2 & 49 & 30 & 55 & 15 & 81 & 51 & 44 & 5 \\
\hline 16 & High & Fine sand & 1.45 & 128 & 2.29 & 2 & 76 & 81 & 17 & 2 & 84 & 50 & 47 & 3 \\
\hline 17 & High & Fine sand & 2.98 & 120 & 3.06 & 3 & 62 & 42 & 49 & 9 & 69 & 25 & 63 & 12 \\
\hline 18 & High & Fine sand & 2.76 & 136 & 3.79 & 4 & 59 & 25 & 65 & 10 & 46 & 20 & 62 & 18 \\
\hline 19 & High & Fine sand & 2.91 & 137 & 3.95 & 5 & 50 & 13 & 75 & 12 & 27 & 10 & 71 & 19 \\
\hline 20 & High & Fine sand & 2.86 & 120 & 3.61 & 6 & 1 & 99 & 1 & 0 & 11 & 0 & 73 & 27 \\
\hline 21 & High & Fine sand & 3.9 & 120 & 3.60 & 4 & 52 & 26 & 61 & 13 & 54 & 21 & 64 & 15 \\
\hline 22 & High & Fine sand & 5.19 & 120 & 3.60 & 4 & 46 & 19 & 63 & 18 & 45 & 20 & 62 & 18 \\
\hline 23 & High & Fine sand & 5.97 & 120 & 3.70 & 4 & 46 & 24 & 57 & 19 & 40 & 16 & 63 & 21 \\
\hline 24 & High & Fine sand & 7.00 & 120 & 3.70 & 4 & 39 & 12 & 65 & 23 & 37 & 20 & 60 & 20 \\
\hline 25 & High & Fine sand & 3.87 & 120 & 1.85 & 4 & 31 & 21 & 62 & 17 & 50 & 11 & 69 & 20 \\
\hline 26 & High & Fine sand & 3.90 & 120 & 3.61 & 4 & 53 & 30 & 57 & 13 & 51 & 19 & 62 & 19 \\
\hline 27 & High & Fine sand & 3.89 & 120 & 4.54 & 4 & 58 & 35 & 53 & 12 & 53 & 23 & 57 & 20 \\
\hline 28 & High & Fine sand & 3.90 & 120 & 5.50 & 4 & 62 & 39 & 50 & 11 & 52 & 23 & 57 & 20 \\
\hline
\end{tabular}

Table 2 Experimental conditions, observed (Jin and Romkens, 2001) and modelled sediment trap efficiency with GUSED-VBS 2 
Table 3 Model performance indicators for three predicted variables of importance to the effectiveness of vegetation buffer strips using data from Jin and Romkens (2001)

\begin{tabular}{llllll}
\hline Variable & Bias & Ec & RMSE & RMSE\% & PWM \\
\hline Water depth in grass strip $(\mathrm{m})$ & 1.07 & 0.95 & 0.01 & 8 & 1.05 \\
Efficiency in trapping sediment (\%) & 0.99 & 0.58 & 12.70 & - & 0.78 \\
Fraction of different size classes in the outflow (\%) & 1.01 & 0.67 & 6.62 & 69 & 0.87 \\
\hline
\end{tabular}

As shown in Table 3, the model predicts water depth within the grass strip with high accuracy. The model predictions for the efficiency of grass strips in reducing sediment concentration and the particle size distribution in the outflow are also quite accurate. Fig 2 shows the observed and modelled efficiencies for a total of 28 runs of the flume experiment.

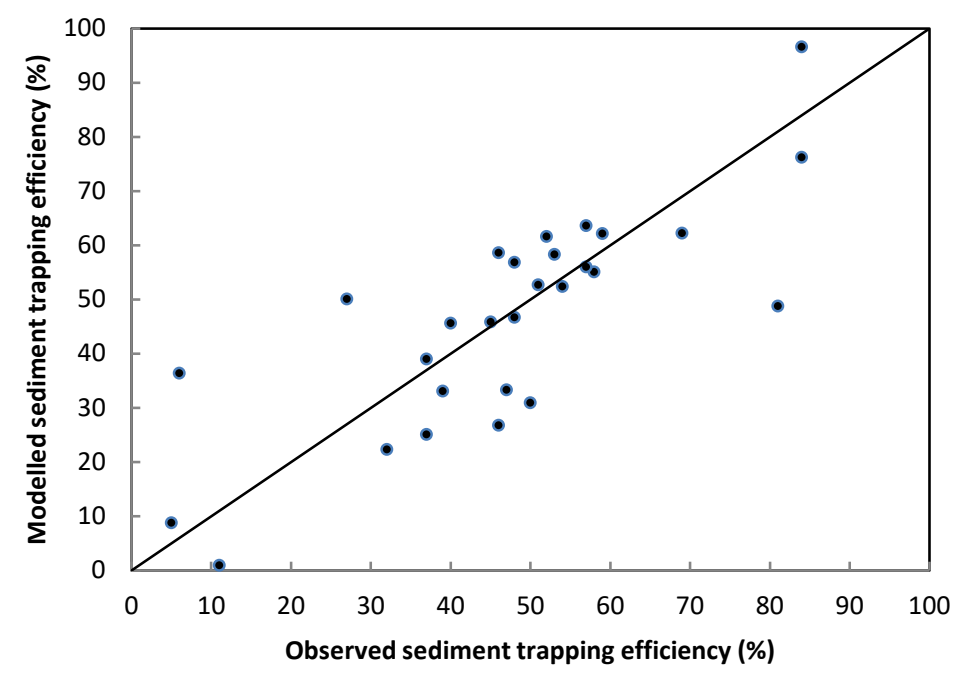

Fig 2 Observed versus modelled efficiency of grass strips in reducing sediment outflow

The distribution of different particle size classes in the deposited sediment upstream the grass strip for different inflow particle distributions is shown in Fig 3. The fraction of fine particles is less than that of in the inflow in both observed and modelled data. The model has predicted that there cannot be any deposition of particles finer than $106 \mu \mathrm{m}$ in the upstream area, while it actually happened. However the fraction of particles finer than $106 \mu \mathrm{m}$ in the observed deposited sediment upstream the grass strip was considerably lower than that of in the inflow. The proportion of coarse particles was higher than that of in the inflow in both observed and modelled data while the model over-predicts it in the upstream region.

Underestimation of fine sediments in the deposited layer in this study was also noted in Hussein et al. (2007b), and Beuselinck et al. (2002). This underestimation suggests that there may be structural deficiency in the way stream power is partitioned according to different size classes. 

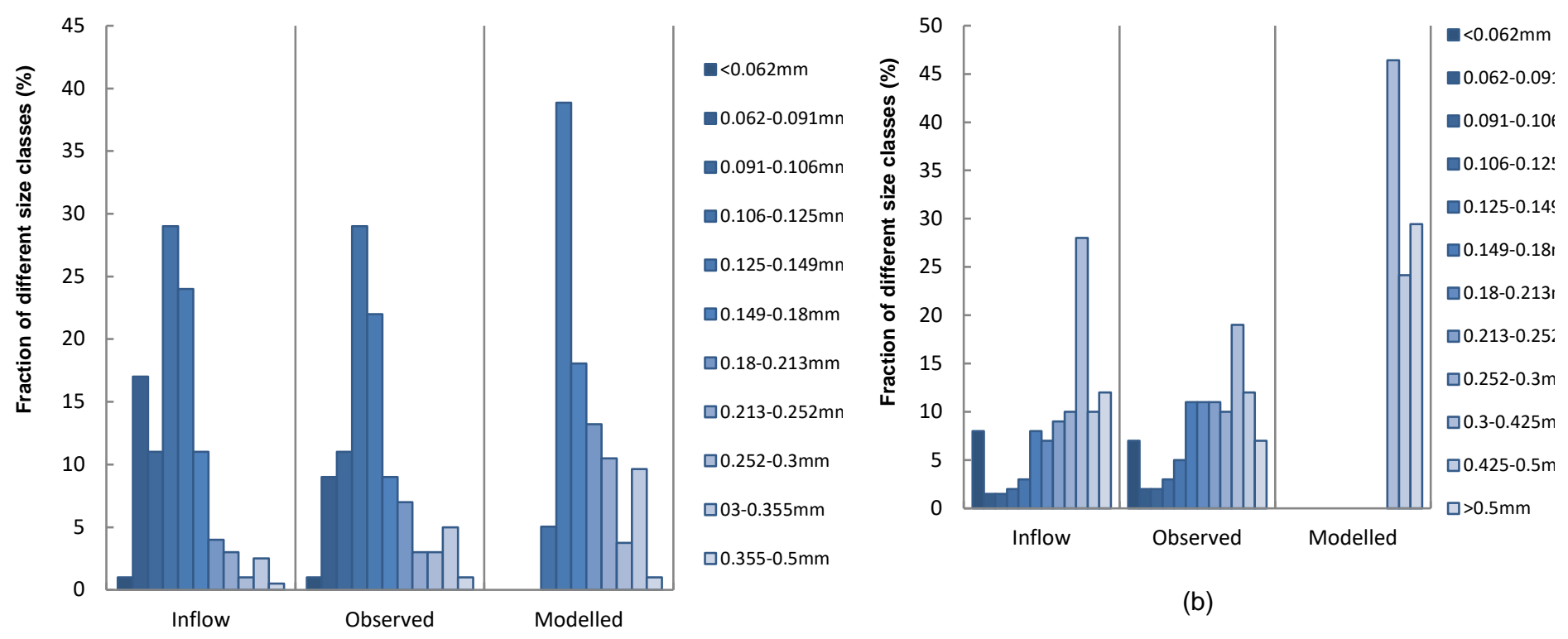

(a)

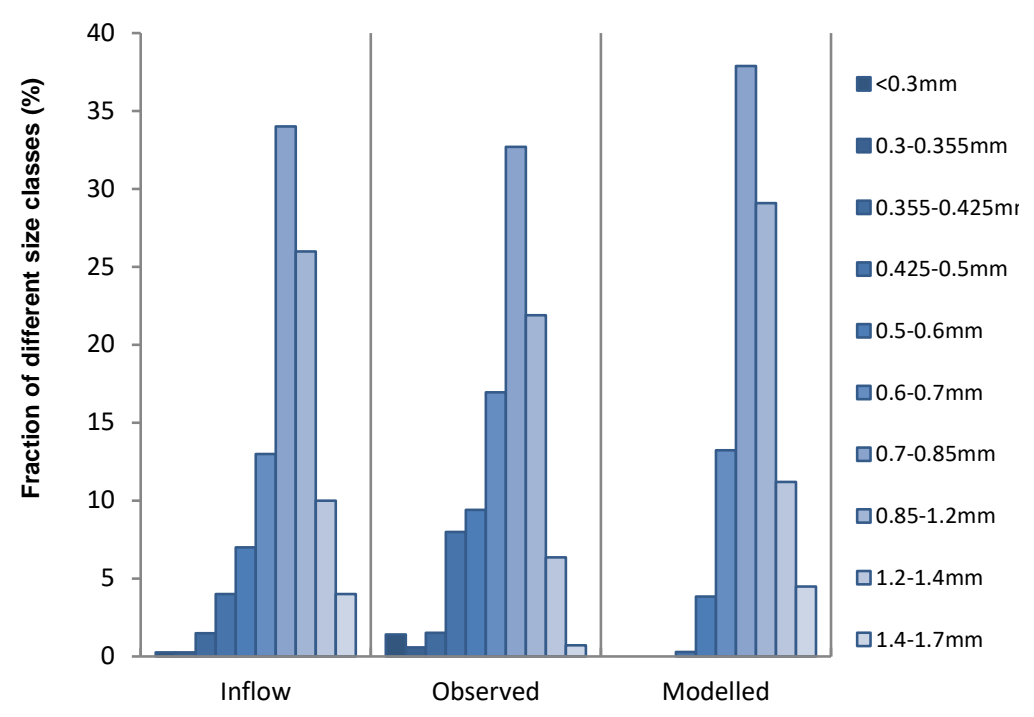

(c)

Fig 3 The proportion of different particle size classes in deposited sediment upstream grass strip. a) Run 02, b) Run 05, c) Run 07

Fig 4 shows the observed and modelled distribution of different particle size classes in the deposited sediment in the upper half of the grass strip for different inflow sediment types. The proportion of finer particles is higher in this area compared to the upstream region in both modelled and observed data. As the model over-predicted the proportion of coarse particles in the deposited sediment upstream the grass strip, consequently the predictions show lower fraction of coarse particles in the upper half deposited sediment. 

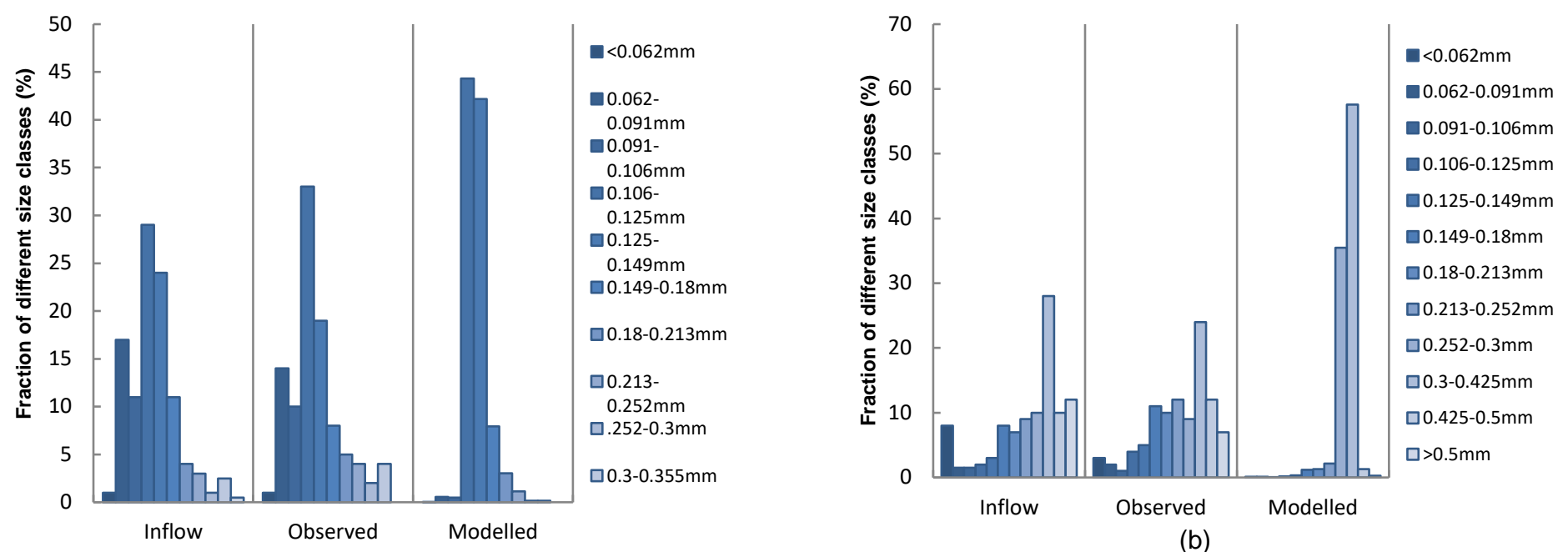

(a)

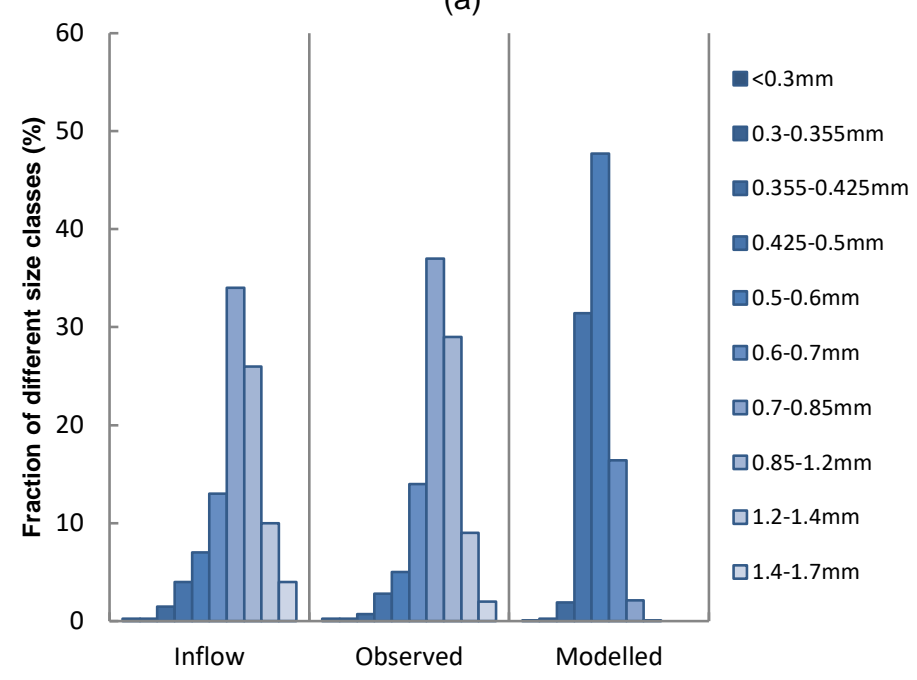

(c)

Fig 4 Distribution of different particle size classes in deposited sediment in the upper half of grass strip. a) Run 02, b) Run 05, c) Run 07

Fig 5 depicts the observed and modelled particle size distribution in the outflow. The results presented in Table 3 showed that the particle size distribution prediction results are acceptable. The proportion of fine particles in the outflow is higher than the inflow in observed and modelled data. Coarse particles are settled more in model predictions than the observed outflow. As Fig 5 shows there is no significant difference in the outflow size distribution for both observed and modelled data in different flow rates. The proportion of coarse particles increases as the bed slope increases in both observed and modelled outcomes. 


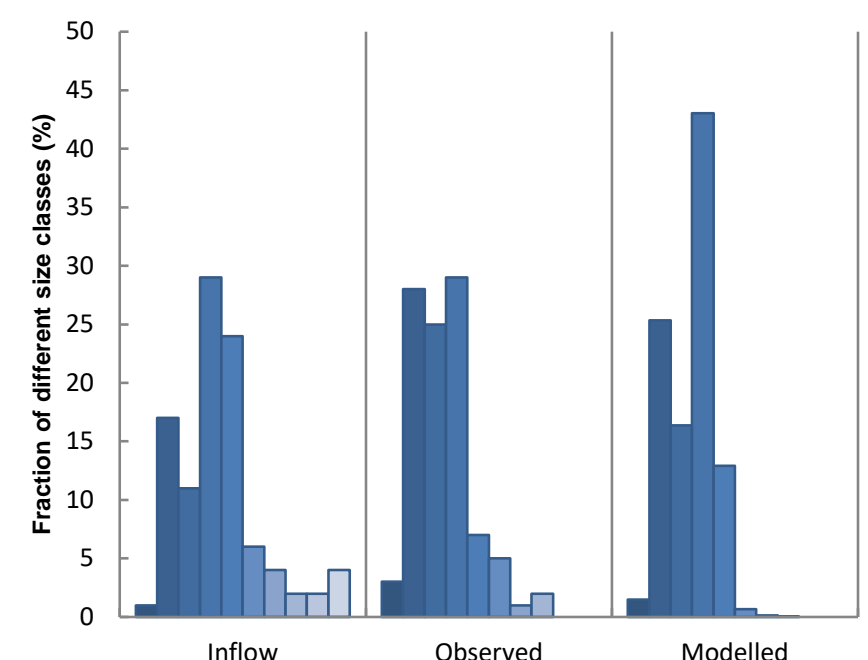

(a)

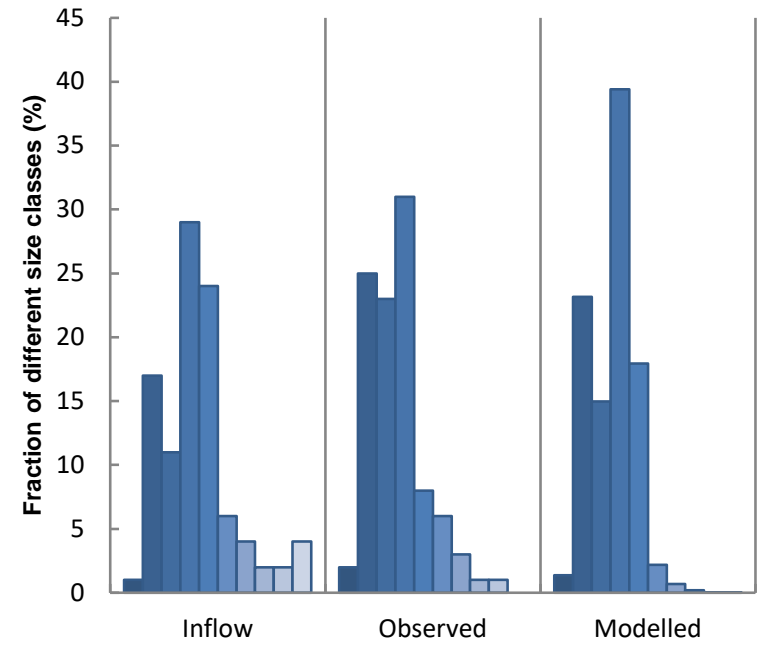

(c)

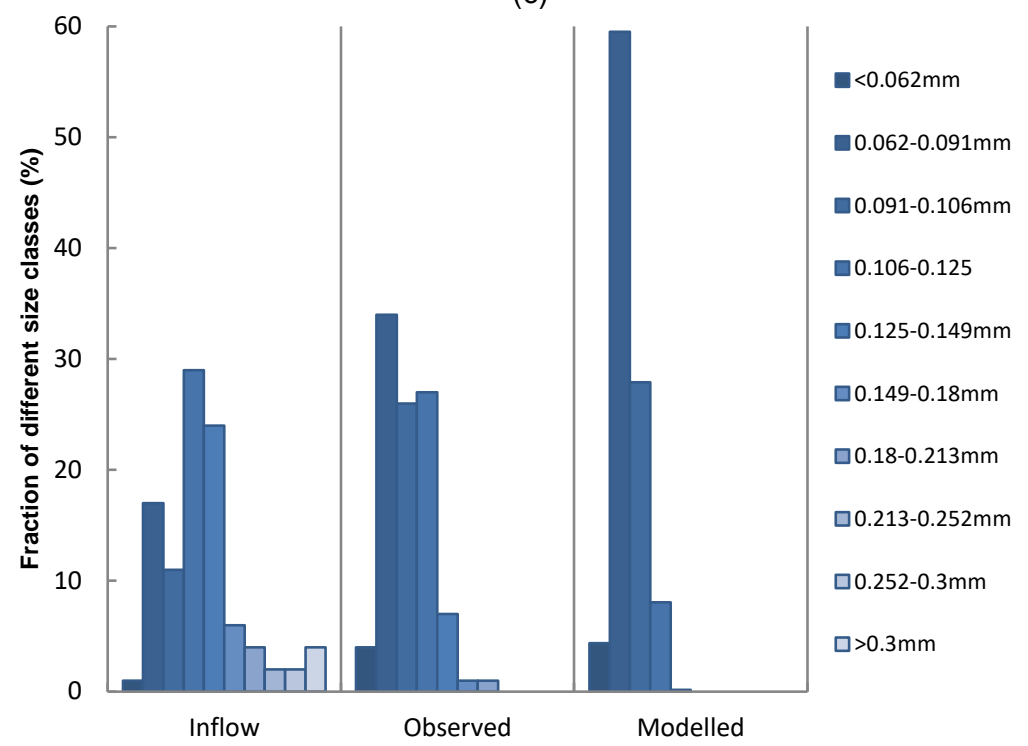

(e)

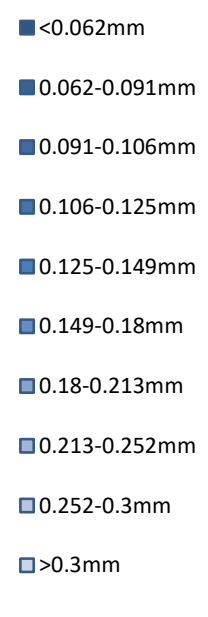

$0.062-0.091 \mathrm{~mm}$

$0.091-0.106 \mathrm{~mm}$

$0.106-0.125 \mathrm{~mm}$

$0.125-0.149 \mathrm{~mm}$

$0.149-0.18 \mathrm{~mm}$

$\square 0.18-0.213 \mathrm{~mm}$

$\square 0.213-0.252 \mathrm{~mm}$

$\square 0.252-0.3 \mathrm{~mm}$

$\square>0.3 \mathrm{~mm}$

$\square .062-0.091 \mathrm{~mm}$
$\square .091-0.106 \mathrm{~mm}$
$\square 0.106-0.125$
$\square 0.125-0.149 \mathrm{~mm}$
$\square 0.149-0.18 \mathrm{~mm}$
$\square 0.18-0.213 \mathrm{~mm}$
$\square 0.213-0.252 \mathrm{~mm}$
$\square 0.252-0.3 \mathrm{~mm}$
$\square>0.3 \mathrm{~mm}$

)

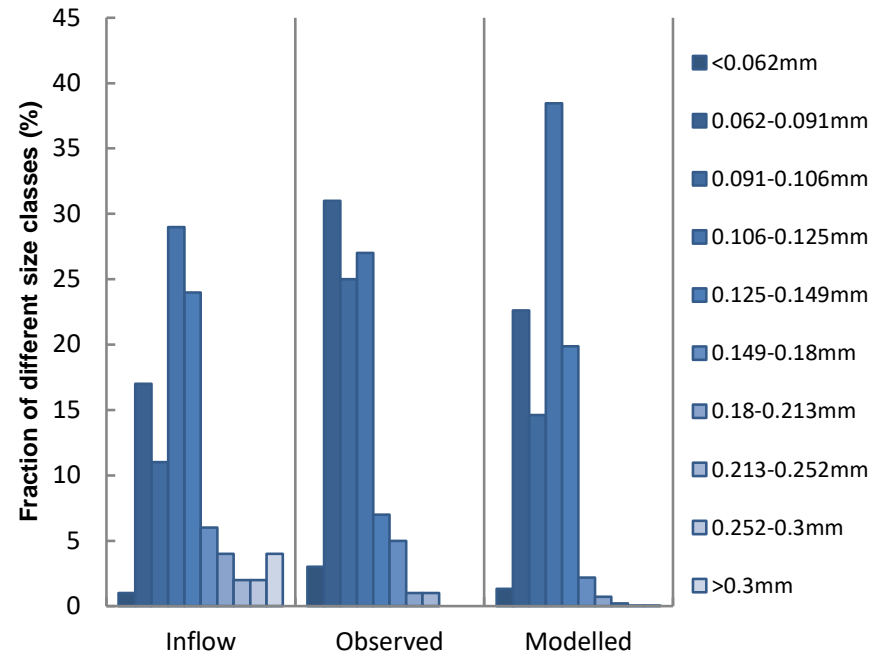

(b)

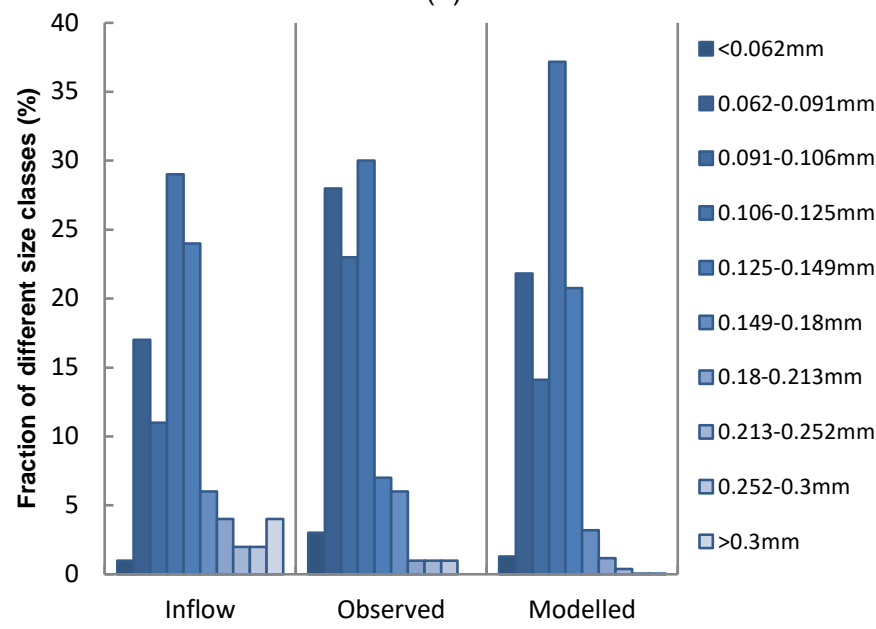

(d)

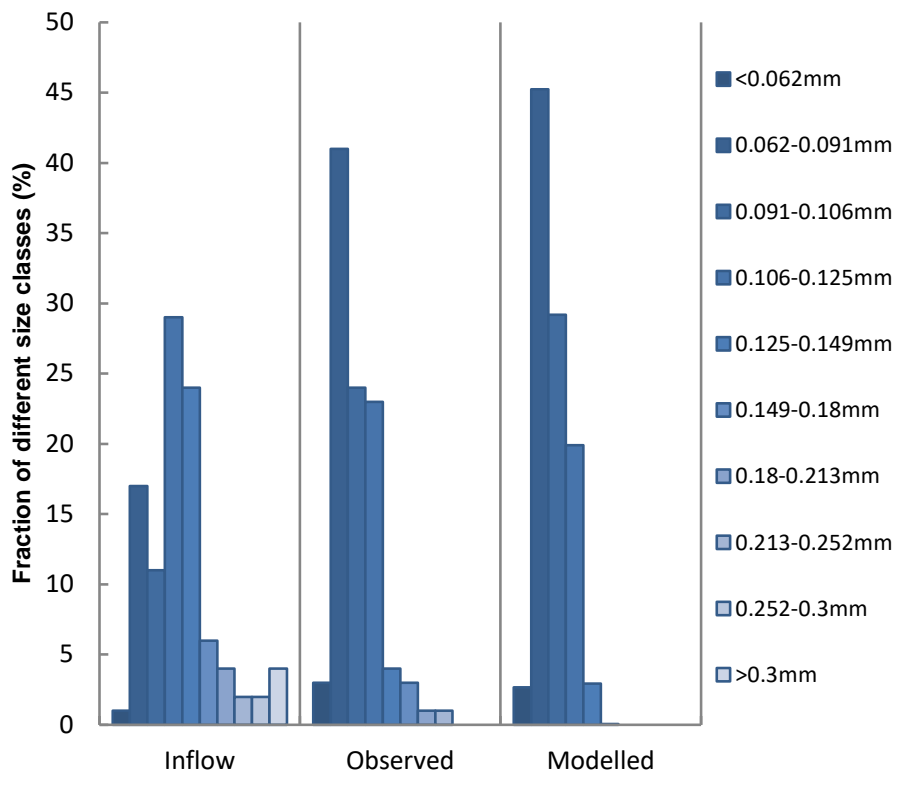

(f) 


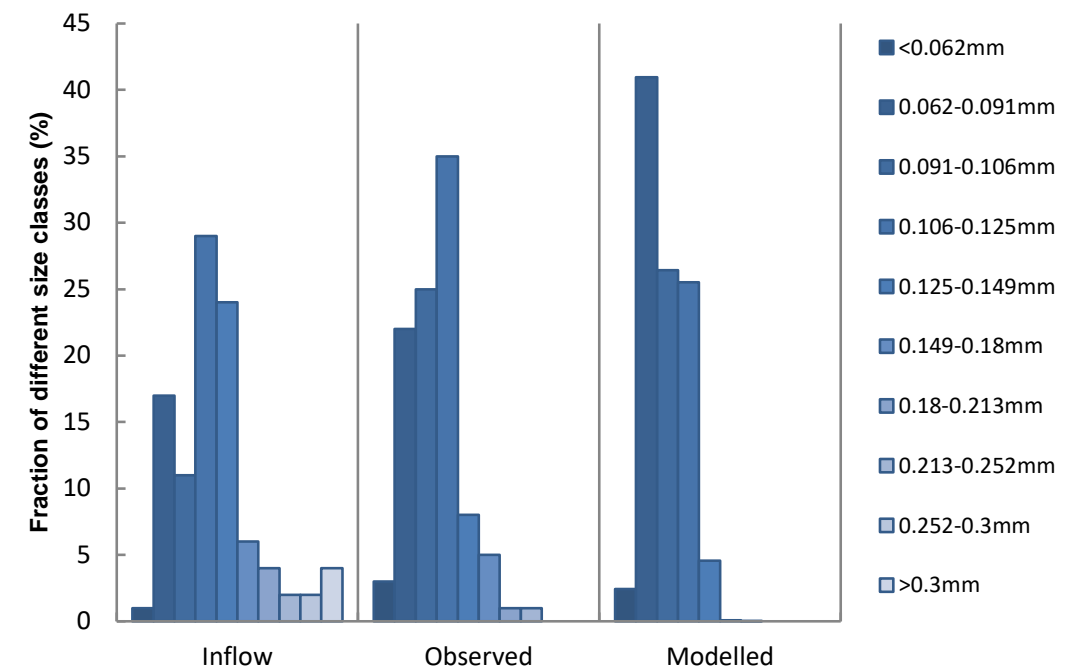

(g)

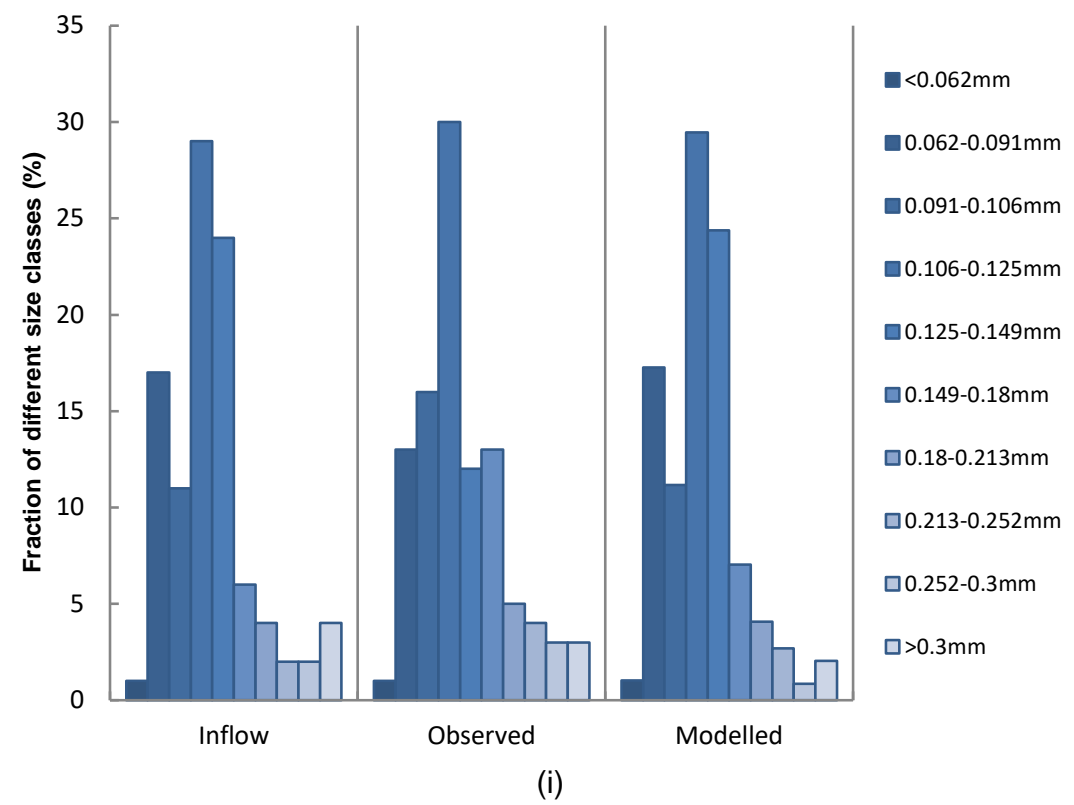

Fig 5 Distribution of different particle size classes ( $\mu \mathrm{m})$ in the outflow. a) Run 08, b) Run 09, c) Run 10, d) Run 11, e) Run S2, f) Run S3, g) Run S4, h) Run S5, i) Run S6

Hussein et al. (2006) experiment:

The model was run for different scenarios tested in the second set of experiments (Hussein et al., 2006) and the performance indicators for this set of experiments are shown in Table 4. Table 5 shows the conditions in every test and the observed and modelled sediment trapping efficiencies. 
Table 4 Model performance indicators for three predicted variables of importance to the effectiveness of vegetation buffer strips using data from Hussein et al. (2006)

\begin{tabular}{llllll}
\hline Variable & Bias & Ec & RMSE & RMSE\% & PWM \\
\hline Water depth in grass strip (m) & 0.99 & 0.98 & 0.01 & 3.1 & 0.99 \\
Efficiency in trapping sediment (\%) & 0.93 & -7.35 & 8.91 & - & 0.88 \\
Fraction of different size classes in the outflow (\%) & 1.00 & 0.82 & 0.13 & 73 & 0.87 \\
\hline
\end{tabular}

Table 5 Modelled and observed results (Hussein et al., 2006)

\begin{tabular}{lllllll}
\hline Test & $\begin{array}{l}\text { Sediment } \\
\text { type }\end{array}$ & $\begin{array}{l}\mathrm{Q} \\
\left(\mathrm{m}^{2}\right. \\
\left.{ }^{3}\right)\end{array}$ & $\mathrm{s}^{-1} \times 10^{-}$ & $\mathrm{c}\left(\mathrm{kg} \mathrm{m}^{-3}\right)$ & $\begin{array}{l}\text { So (\%) } \\
\text { Modelled } \\
\text { efficiency } \\
(\%)\end{array}$ & $\begin{array}{l}\text { Observed } \\
\text { efficiency (\%) }\end{array}$ \\
\hline 1 & Podzol & 1.00 & 4.7 & 5.0 & 87 & 94 \\
2 & Ferralsol & 1.00 & 4.7 & 5.0 & 97 & 97 \\
3 & Vertisol & 0.33 & 25.1 & 1.0 & 95 & 94 \\
4 & Vertisol & 0.66 & 13.7 & 3.0 & 81 & 90 \\
5 & Vertisol & 1.00 & 8.9 & 5.0 & 72 & 88 \\
\hline
\end{tabular}

Fig 6 shows the observed and modelled particle size distribution in the outflow sediment. As Fig 6 shows the fraction of fine particles leaving the grass strip is significantly higher than that in the inflow, and the model accurately predicts it. The accuracy of model in predicting the fraction of different particle sizes in the outflow is higher in 5\% slope than $1 \%$.

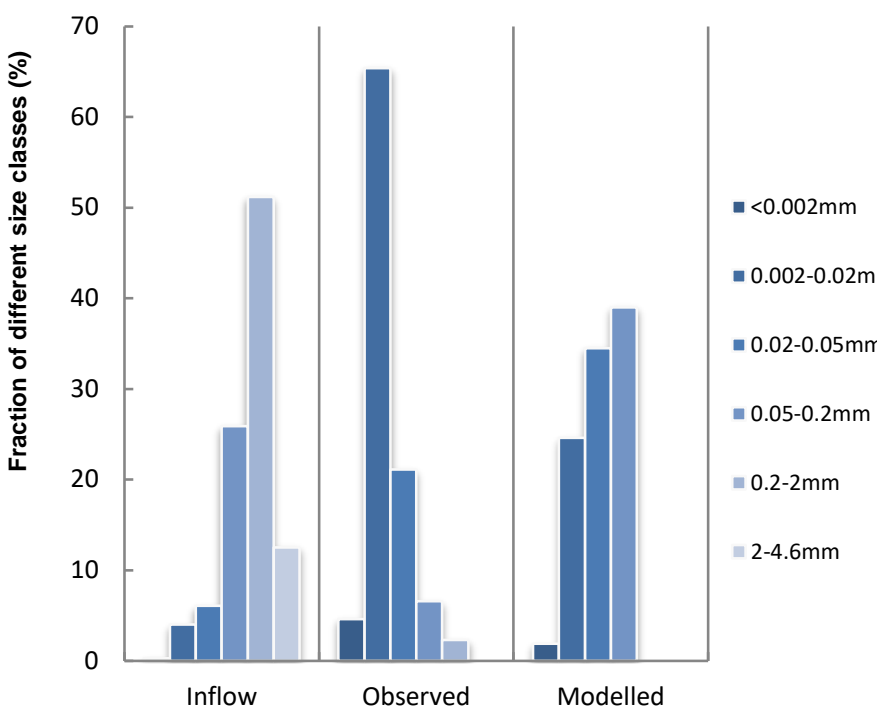

(a)

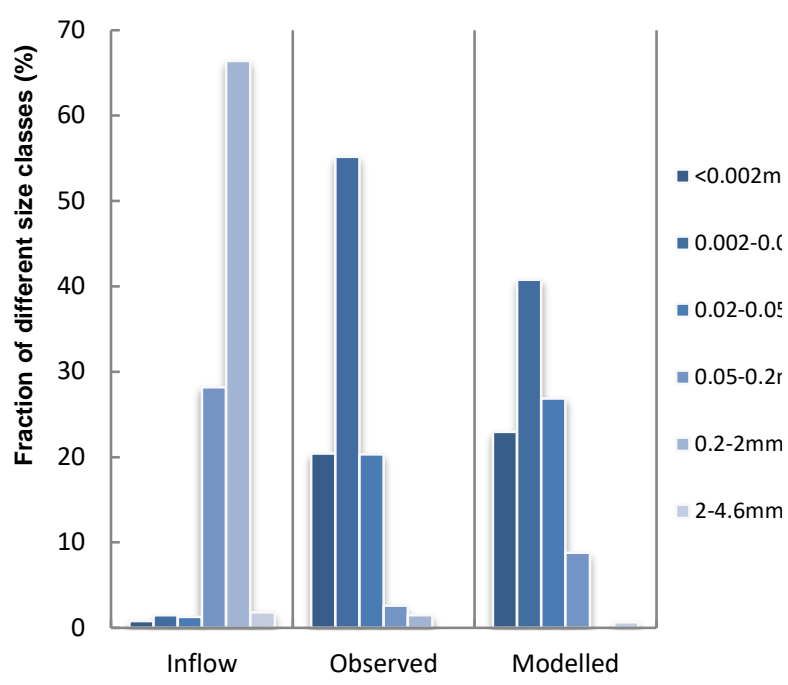

(b) 

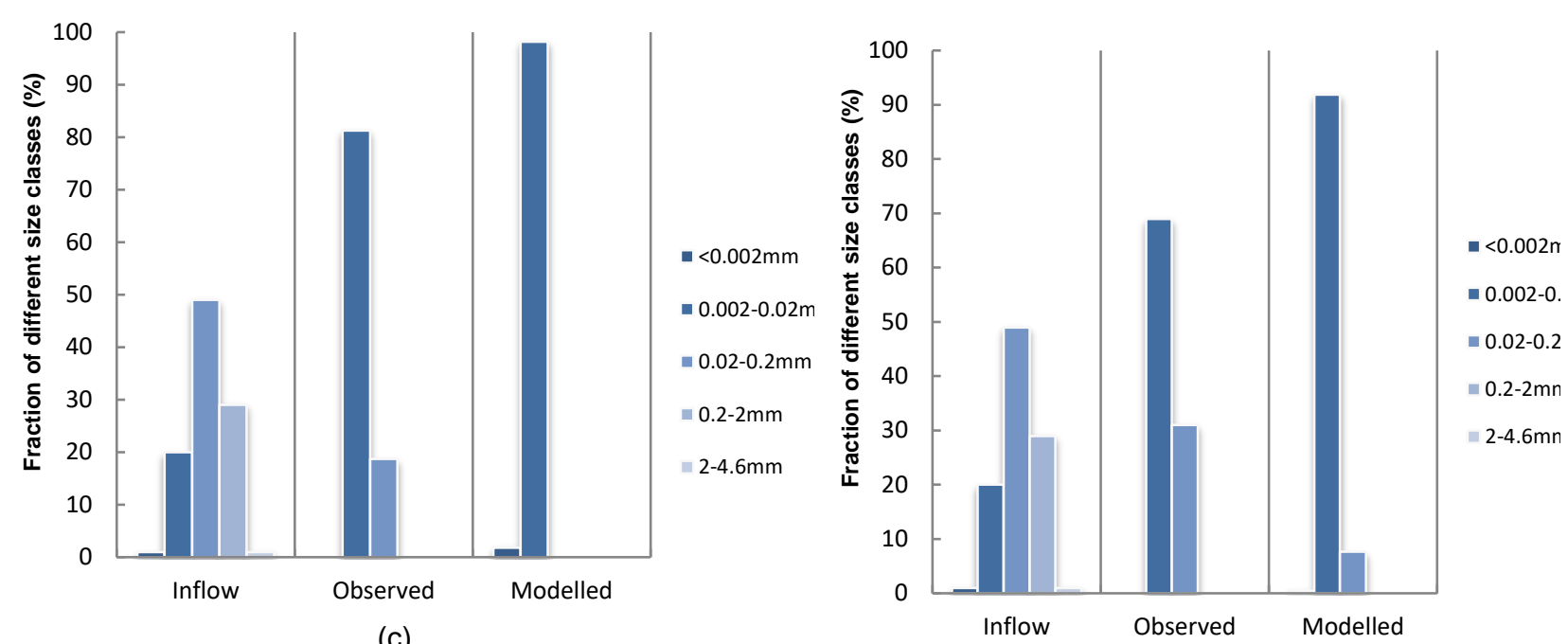

(d)

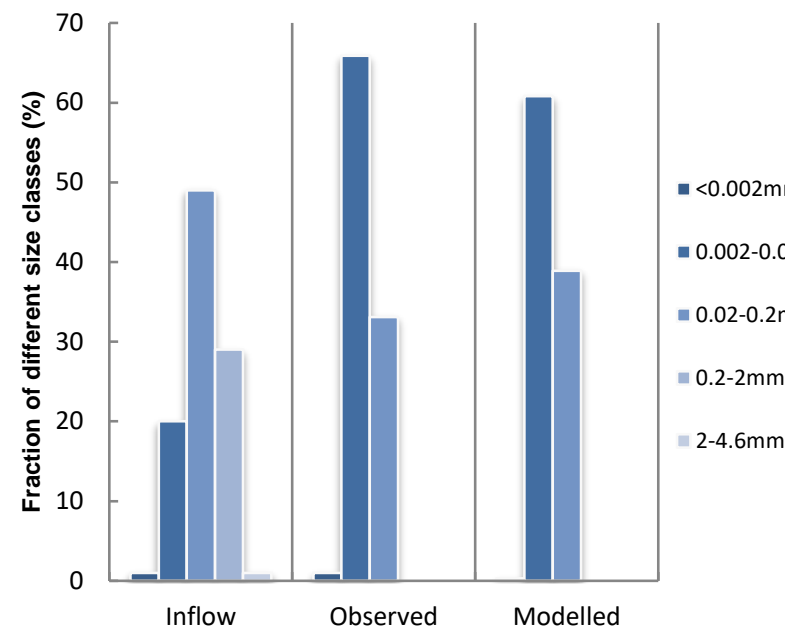

(e)

Fig 6 Distribution of different particle size classes in the outflow. a) Farrolsol, 5\% slope, b) Podzol 5\% slope c) Vertisol $1 \%$ slope, d) Vertisol 3\% slope, e) Vertisol $5 \%$ slope

\section{Discussion}

High resistance of the grassed area and high infiltration capacity within the grass strip enhance sediment deposition upstream and within the buffer strips. Changes to the water profile because of the presence of grass strips reduce the flow friction slope and consequently the stream power. This increases the deposition rate compared to non-grassed areas. Infiltration not only reduces the mass of sediment in the outflow, but also lowers the flow velocity by decreasing the flow rate, which enhances settling of particles.

As an illustration, Fig. 7 shows a slope of $1 \mathrm{~m}$ in length with $50 \mathrm{~cm}$ upstream and $50 \mathrm{~cm}$ within the grass strip, and the modelled water surface and deposited sediment profiles in a hypothetical 
grass strip after 10 and 30 minutes of a runoff event. The particle size distribution is the same as the fine sand in Jin and Romkens (2001) test. As Fig. 7 shows the deposited sediment increases over time, and the location where the maximum rate of deposition occurs migrates towards the grass strip. The length and depth of the backwater region upstream of the grass strip increases over time. The reason is that the depth and length of deposited sediment in the upstream area increases in time. The rate of deposition in the grassed area is much lower compared to the upstream region because of the high rate of deposition of coarser particles upstream of the grass strip. The flow velocity is also higher within the grass strip than in the upstream section. Fig 7 also shows that the water depth decreases slightly towards the exit end of buffer strip due to infiltration, and the decrease becomes less pronounced with time as infiltration is reduced from the $10^{\text {th }}$ to $30^{\text {th }} \mathrm{min}$.

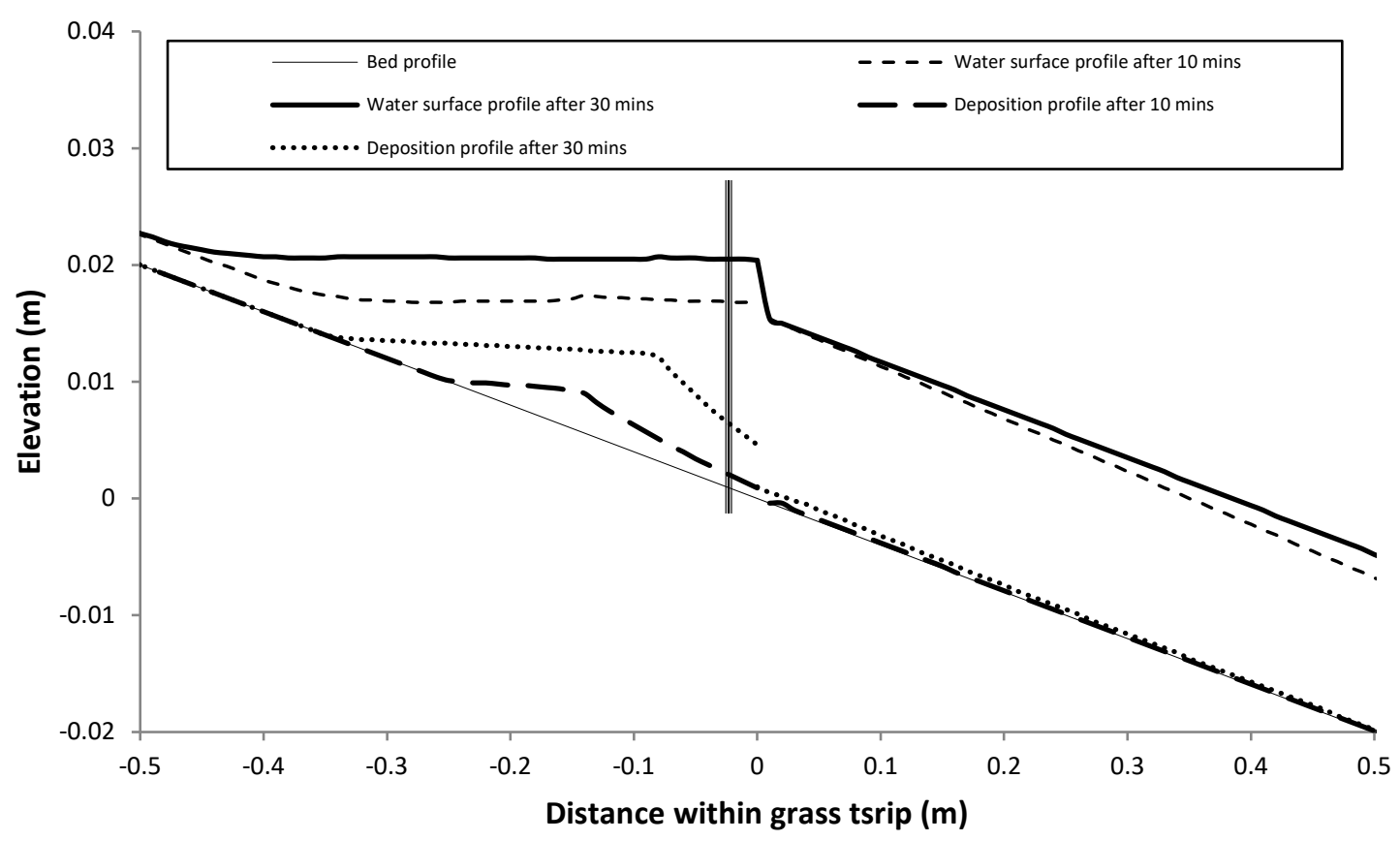

Fig 7 Simulated water surface and deposited sediment profile upstream and within grass strip with

$$
\mathrm{q}=0.001 \mathrm{~m}^{2} \mathrm{~s}^{-1}, \mathrm{~S}_{0}=4 \%, \mathrm{n}=0.2, \mathrm{Ks}=10^{-5} \mathrm{~m} \mathrm{~s}^{-1}, \theta_{\mathrm{s}}=0.43 \text {, and } \theta_{i}=0.3
$$

Sensitivity analysis was performed to estimate the uncertainty of the model outputs based on uncertainty in different input parameters. The ranges of input parameters for conducting the sensitivity analysis are presented in Table 6. The minimum and maximum values of these parameters all differ by a factor of 4 to allow a consistent comparison. The distribution of particle size classes is the same as the fine sand in the Jin and Romkens (2001) experiment. The fixed values of the parameters are presented in Table 6. Sensitivity of these 7 parameters was evaluated one at a time. When the value of a parameter was changed, the remaining 
parameters were held at these fixed values according to Table 6. In order to be able to compare the effectiveness of different parameters in reducing runoff, and sediment concentration and mass, parameters were normalised as following:

$\dot{X}=\frac{X-X_{\min }}{X_{\max }-X_{\min }}$

where $X^{\prime}$ is the normalised factor, $X$ is a model parameter, and $X_{\min }$ and $X_{\max }$ are the minimum and maximum values of this parameter respectively.

Table 6 Range of input parameters for sensitivity analysis

\begin{tabular}{llllllll}
\hline Parameter & $\mathrm{q}\left(\mathrm{m}^{2} \mathrm{~s}^{-1}\right)$ & Manning's $\mathrm{n}$ & $\mathrm{L}(\mathrm{m})$ & $\mathrm{K}_{\mathrm{s}}\left(\mathrm{m} \mathrm{s}^{-1}\right)$ & $\theta_{\mathrm{i}}$ & $\mathrm{S}_{0}(\%)$ & Duration (min) \\
\hline Range & $0.0005-.002$ & $0.1-0.4$ & $1-4$ & $2^{\star} 10^{-5}-8^{\star} 10^{-5}$ & $0.1-0.4$ & $2-8$ & $20-80$ \\
Fixed value & 0.001 & 0.2 & 2 & $4^{\star} 10^{-5}$ & 0.3 & 4 & 40 \\
\hline
\end{tabular}

The effect of different parameters on runoff reduction is showed in Fig 8. As shown in the figure the performance of grass strips in reducing runoff is most sensitive to the initial soil moisture. When the initial soil moisture is high the efficiency of grass strips in runoff reduction is dramatically lower compared to initially dry soils. Fig 8 also shows that changes in flow rate effects the performance of grass strips in runoff reduction. As flow rate increases from low to medium and high, the volume of water infiltrating into the soil dramatically decreases. The length of the grass strip is also as effective as the flow rate. The runoff reduction is considerably higher in long strips compared to short ones. Slope steepness and hydraulic roughness did not have significant effects on runoff reduction, so are not illustrated in Fig 8.

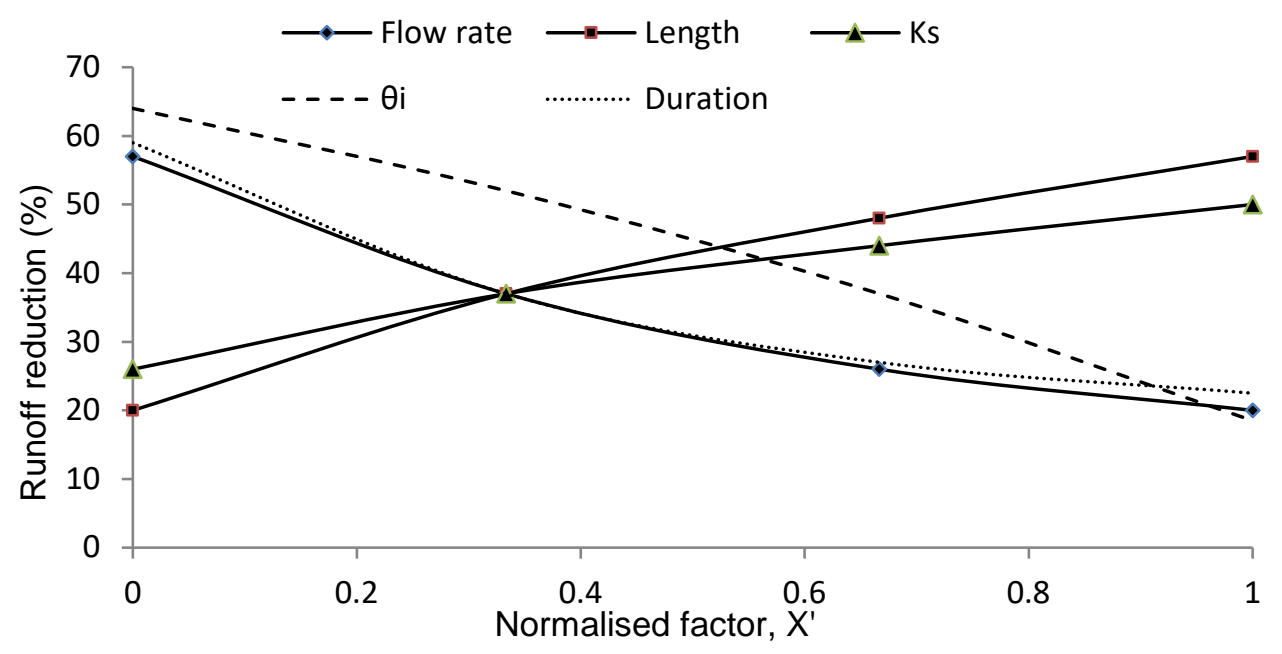

Fig 8 Effectiveness of different factors in efficiency of grass strip in runoff reduction 
Fig 9 shows the sensitivity of grass strips to variation in different parameters in reducing sediment concentration in the outflow. Slope steepness is most sensitive to the reduction in outflow sediment concentration due to grass strips. As slope increases from $2 \%$ to $8 \%$ the backwater region upstream of the grass strips tends to contract to an area close to the grass strip, hence limits the amount of deposition upstream and leads to higher sediment concentrations in the outflow. The rate of sediment deposition decreases at high slopes due to higher flow velocities. Stream power is also higher in steeper slopes which enhances the reentrainment process. The efficiency of grass strips in reducing sediment concentration also decreases dramatically as the flow rate increases.

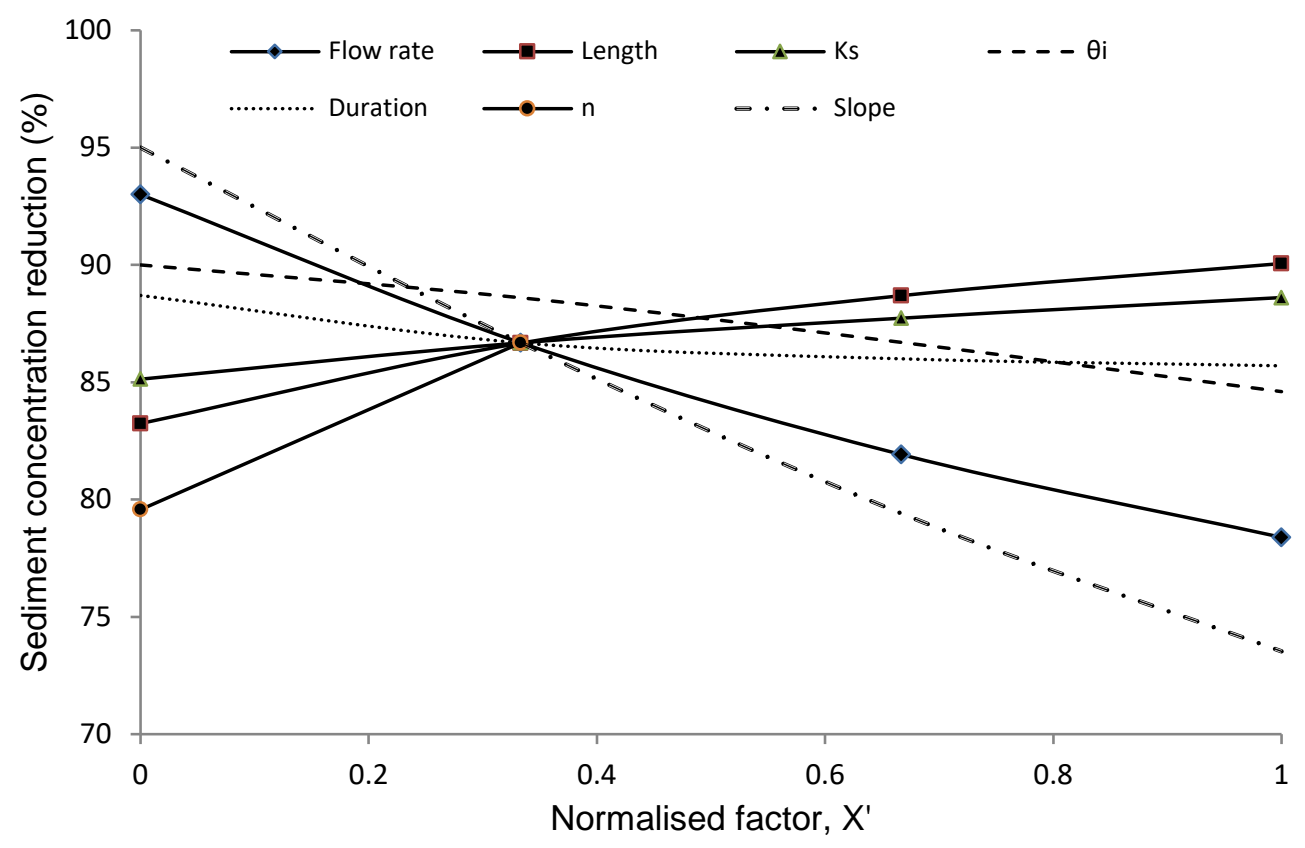

Fig 9 Effectiveness of different factors in efficiency of grass strip in reducing sediment concentration

Fig 10 illustrates changes in sediment mass reduction in grass strips with changes in input parameters. Similar to Fig 9, slope is the most important factor in reducing sediment mass. The significance of flow rate in sediment delivery reduction by grass strips is almost as high as slope steepness since the efficiency of grass strips in reducing sediment delivery is considerably lower in high flow rates compared to low ones. The effect of initial soil moisture is more pronounced in reducing sediment delivery than concentration. 


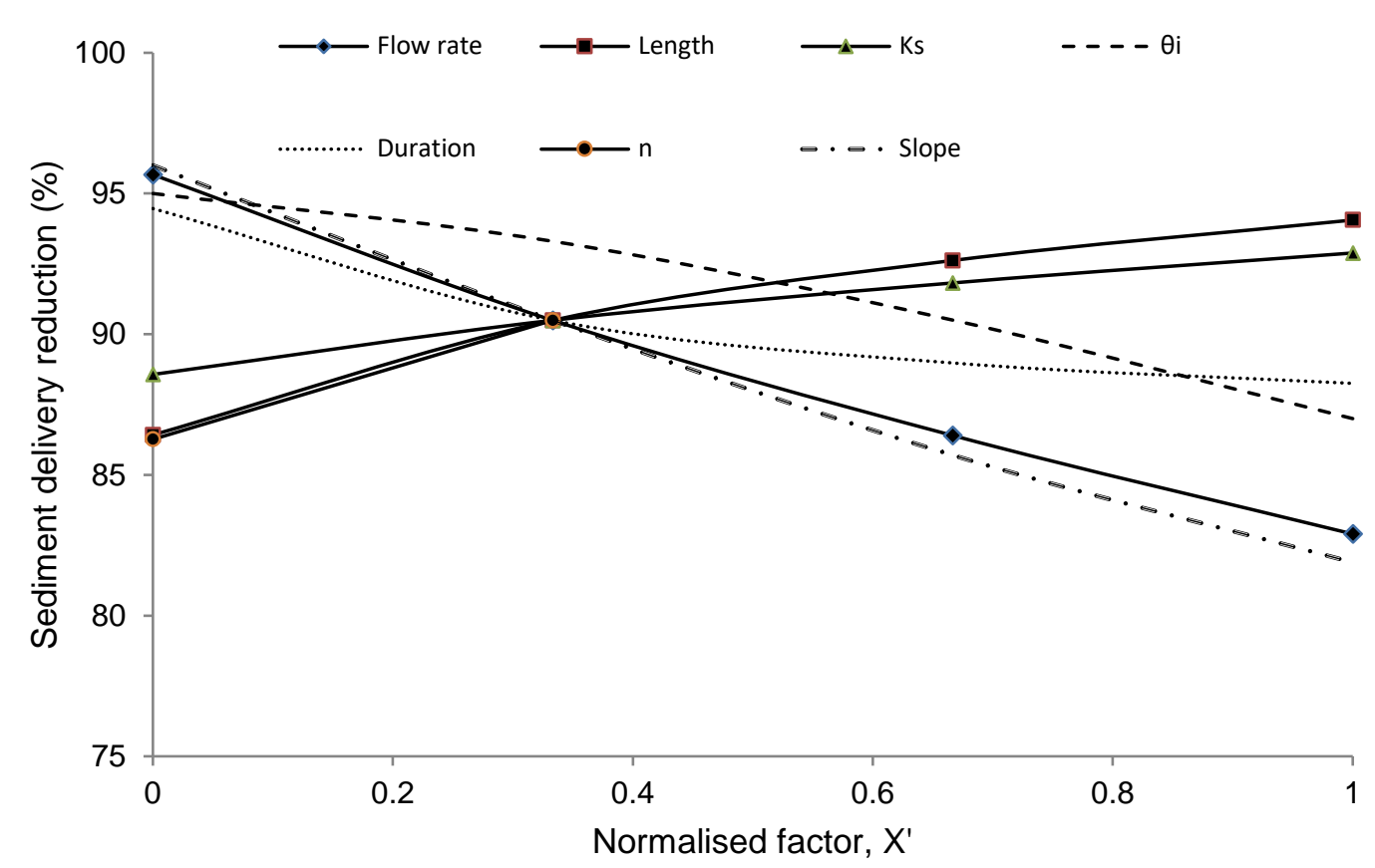

Fig 10 Effectiveness of different factors in efficiency of grass strip in reducing mass of sediment

\section{Conclusions}

A process-based model was developed in order to simulate and predict the fate of water and sediment in and around grass strips. As the size of sediment particles is very important in the use of the model for water pollution predictions, the model calculates the concentration and mass of sediment in the outflow for different particle size classes separately. The model consists of hydrology and sediment transport sub-models. The two sub-models primarily model flow and sediment transport in the backwater area upstream of the grass strip and these backwater simulation results specify the conditions of the upstream edge of grass strips.

Modified Green-Ampt method is used to calculate the infiltration rate over time and distance. Gradually varied flow equation and kinematic wave approximation were used to simulate flow characteristics upstream and within the grass strip. The Hairsine and Rose (1992) module for predicting water erosion and deposition in sheet flow is modified in order to be used in grass strip.

The model outputs were compared with the results of two different sets of experiments carried out under controlled conditions. The model predictions of flow and sediment transport characteristics were accurate. Although the particle size distribution in the outflow matched 
well with the experimental results, the proportion of fine particles in the deposited sediment upstream of the grass strip was higher in the observed data. As the slope increased, the observed and predicted proportion of coarse particles in the outflow increased.

In agreement with the experimental observations, the model predicted the proportion of coarse particles to be higher in the deposited material upstream of the grass strip compared to the deposited material within the grass strip. Although most deposition occurs in the backwater region and the top sections of the grass strip in low slopes, long grass strips are required to trap considerable amount of sediment in extreme conditions such as heavy storms in steep lands.

The sensitivity analysis showed that the initial soil moisture of the grass buffer strip is the most sensitive parameter in predicting runoff loss. Increase in slope steepness and flow rate dramatically decreases the efficiency of grass strips in reducing sediment concentration and delivery. The efficiency of grass strips reduces over time during the runoff events.

\section{References}

Abu-Zreig, M., Rudra, R.P., Lalonde, M.N., Whiteley, H.R., Kaushik, N.K., 2004. Experimental investigation of runoff reduction and sediment removal by vegetated filter strips. Hydrological Processes, 18(11): 2029-2037.

Akram, S., Yu, B., Ghadiri, H., Rose, C., Hussein, J., 2014. The links between water profile, net deposition and erosion in the design and performance of stiff grass hedges. J Hydrol, 510(0): 472479.

Andriyas, S., Negi, S.C., Rudra, R.P., Yang, S.X., 2003. Modelling Total Suspended Solids in Vegetative Filter Strips using Artificial Neural Networks, 2003 ASAE Annual Meeting. ASAE, Las Vegas, Nevada, USA.

Beuselinck, L., Hairsine, P.B., Sander, G.C., Govers, G., 2002. Evaluating a multiclass net deposition equation in overland flow conditions. Water Resour Res, 38(7): 14-1-14-11.

Cheng, N., 1997. Simplified Settling Velocity Formula for Sediment Particle. Journal of Hydraulic Engineering, 123(2): 149-152.

Dabney, S.M., Mcgregor, K.C., Meyer, L.D., Grissinger, E.H., Foster, G.R., 1993. Vegetative Barriers for Runoff and Sediment Control. Asae Publ, 93(13): 60-70

387.

Deletic, A., 1999. Sediment behaviour in grass filter strips. Water Sci Technol, 39(9): 129-136.

Deletic, A., 2000. Sediment behaviour in overland flow over grassed areas, University of Aberdeen.

Deletic, A., 2001. Modelling of water and sediment transport over grassed areas. J Hydrol, 248(14): 168-182.

Deletic, A., 2005. Sediment transport in urban runoff over grassed areas. J Hydrol, 301(1-4): 108122.

Deletic, A., Fletcher, T.D., 2006. Performance of grass filters used for stormwater treatment - a field and modelling study. J Hydrol, 317(3-4): 261-275.

Flanagan, D.C., Nearing, M.A., 2000. Sediment particle sorting on hillslope profiles in the WEPP model. T Asae, 43(3): 573-583. 
Hairsine, P.B., Rose, C.W., 1992. Modeling Water Erosion Due to Overland-Flow Using Physical Principles .1. Sheet Flow. Water Resour Res, 28(1): 237-243.

Hook, P.B., 2003. Sediment retention in rangeland riparian buffers. J Environ Qual, 32(3): 11301137.

Hussein, J., Ghadiri, H., Yu, B., Rose, C., 2007a. Sediment retention by a stiff grass hedge under subcritical flow conditions. Soil Sci Soc Am J, 71(5): 1516-1523.

Hussein, J., Truong, P., Ghadiri, H., Yu, B., Rose, C., 2006. Vetiver buffer strips: modelling their effect on sediment and nutrient reduction from surface flow, Proceedings of 4th International Vetiver Conference: Vetiver and People. Vetiver International, Caracas, Venezuela.

Hussein, J., Yu, B., Ghadiri, H., Rose, C., 2007b. Prediction of surface flow hydrology and sediment retention upslope of a vetiver buffer strip. J Hydrol, 338(3-4): 261-272.

Jin, C.X., Romkens, M.J.M., 2001. Experimental studies of factors in determining sediment trapping in vegetative filter strips. $T$ Asae, 44(2): 277-288.

Le Bissonnais, Y., Lecomte, V., Cerdan, O., 2004. Grass strip effects on runoff and soil loss.

Agronomie, 24(3): 129-136.

Munoz-Carpena, R., Parsons, J.E., Gilliam, J.W., 1999. Modeling hydrology and sediment transport in vegetative filter strips. J Hydrol, 214(1-4): 111-129.

Nash, J.E., Sutcliffe, J.V., 1970. River flow forecasting through conceptual models part I -- A

discussion of principles. J Hydrol, 10(3): 282-290.

Nearing, M.A., Foster, G.R., Lane, L.J., Finkner, S.C., 1989. A Process-Based Soil-Erosion Model for Usda-Water Erosion Prediction Project Technology. T Asae, 32(5): 1587-1593.

Newham, L., Rutherford, J., Croke, B., 2005. A conceptual model of particulate trapping in riparian buffers. CSIRO Land and Water Technical Report 21/05.

Parsons, J.E., Gilliam, J.W., Munoz-Carpena, R., Daniels, R.B., Dillaha, T.A., 1994. Nutrient and sediment removal by grass and riparian buffers. In: al., K.L.C.e. (Ed.), 2nd Conf.: Environmentally Sound Agriculture. ASAE, St. Joseph, MI, pp. 147-154.

Raffaelle, J.B., McGregor, K.C., Foster, G.R., Cullum, R.F., 1997. Effect of narrow grass strips on conservation reserve land converted to cropland. T Asae, 40(6): 1581-1587.

Rey, F., 2004. Effectiveness of vegetation barriers for marly sediment trapping. Earth Surface Processes and Landforms, 29(9): 1161-1169.

Schmitt, T.J., Dosskey, M.G., Hoagland, K.D., 1999. Filter strip performance and processes for different vegetation, widths, and contaminants. J Environ Qual, 28(5): 1479-1489.

Shrestha, G., Stahl, P.D., Ingram, L., 2005. Influence of Reclamation Management Practices on Soil Bulk Density and Infiltration Rates on Surface Coal Mine Lands in WYOMING. National Meeting of the American Society of Mining and Reclamation. 